\title{
Over-expression of thymosin $\beta 4$ promotes abnormal tooth development and stimulation of hair growth
}

\author{
HEE-JAE CHA*,1, DEBORAH PHILP2 , SOO-HYUN LEE ${ }^{3}$, HYE-SUNG MOON4, \\ HYNDA K. KLEINMAN ${ }^{2}$ and TAKASHI NAKAMURA ${ }^{2}$ \\ ${ }^{1}$ Department of Parasitology and Genetics, College of Medicine, Kosin University, Busan, S. Korea, \\ ${ }^{2}$ Craniofacial Developmental Biology and Regeneration Branch, National Institute of Dental and Craniofa- \\ cial Research, National Institutes of Health, Bethesda, MD, USA, ${ }^{3}$ Department of Pharmaceutics, College of \\ Pharmacy, Seoul National University, Seoul, S. Korea and ${ }^{4}$ Department of Obstetrics and Gynecology, \\ School of Medicine, EWHA Womans University, Seoul, S. Korea
}

\begin{abstract}
Thymosin $\beta 4$ has multi-functional roles in cell physiology. It accelerates wound healing, hair growth and angiogenesis, and increases laminin-5 expression in corneal epithelium. Furthermore, thymosin $\beta 4$ stimulates tumor growth and metastasis by induction of cell migration and vascular endothelial growth factor-mediated angiogenesis. Using a construct on the skinspecific keratin- 5 promoter, we have developed thymosin $\beta 4$ over-expressing transgenic mice to further study its functional roles. Thymosin $\beta 4$ in adult skin and in embryonic stages of the transgenic mouse was analyzed by both Western blot and immunohistochemistry. The overexpression of thymosin $\beta 4$ was observed especially around hair follicles and in the teeth in the transgenic mice. We examined the phenotype of the thymosin $\beta 4$ over-expressing mice. Hair growth was accelerated. In addition, the transgenic mice had abnormally-shaped white teeth and dull incisors. We found that the expression of laminin-5 was up-regulated in the skin of the transgenic mice. We conclude that thymosin $\beta 4$ has an important physiological role in hair growth and in tooth development.
\end{abstract}

KEY WORDS: thymosin $\beta 4$, transgenic mice, hair growth, tooth development, laminin-5

\section{Introduction}

Thymosin $\beta 4$, a $4.9 \mathrm{kDa}$ protein containing 43 amino acids, is an actin-sequestering peptide. It binds with monomeric globular actin and inhibits the polymerization of actin (Safer et al., 1991). Thymosin $\beta 4$ plays an important role in cell motility due to its participation in the rapid polymerization/depolymerization of actin (Pantaloni and Carlier, 1993; Kang et al., 1999). Thymosin $\beta 4$ has multiple biological activities, including promotion of angiogenesis (Grant wt al., 1995; Grant et al., 1999) and wound healing (Philp et al., 2004). Previously, we also showed that thymosin $\beta 4$ stimulates tumor growth and metastasis by induction of cell migration and vascular endothelial growth factor (VEGF)-mediated angiogenesis (Cha et al., 2003). Its role in malignancy has been reported by several labs using transfection approaches, and its level is also elevated in many metastatic lesions (Cha et al., 2003; Wang et al., 2004).

Functional studies using exogenously delivered thymosin $\beta 4$ demonstrated its role in wound healing and in hair growth in both normal rats and mice (Philp et al., 2004). When examining the distribution of endogenous thymosin $\beta 4$ through sequential phases of depilation-induced hair growth, we found that a significant number of thymosin $\beta 4$-expressing cells are present in the developing hair follicle. In addition, isolated clonogenic hair follicle keratinocytes, which are related to hair follicle stem cells, produce thymosin $\beta 4$ when cultured in vitro for 7-10 days. The presence of exogenous thymosin $\beta 4$ causes a dose-dependent decrease in the expression of the stem cell marker $\mathrm{K} 15$ by these cells, suggesting that thymosin $\beta 4$ may promote initial stem cell fate determination (Philp et al., 2004). A critical step in the hair growth cycle is the movement of some of the stem cells downward from bulge region, which is located at the middle of hair follicles and is

Abbreviations used in this paper: CMV, cytomegalo virus; K5, keratin 5 promoter; LM-5, laminin-5; VEGF, vascular endothelial growth factor.

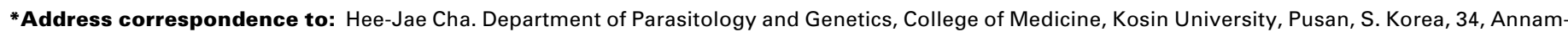
dong, Seo-gu, Busan, 602-703, S. Korea. Fax: +82-51-990-3081. e-mail: hcha@kosin.ac.kr
} 
enriched in stem cells. Their differentiated progeny contribute to complete re-growth or regeneration of the lower, cycling portion of the follicle. Thymosin $\beta 4$ promotes the migration of these stem cells and their immediate progeny and, thus, exerts its promoting effect on hair growth.

Laminin-5 (LM-5) is a unique sub-epithelial basement membrane glycoprotein composed of $\alpha 3 / \beta 3 / \gamma 2$ chains (Burgeson et al., 1994). LM-5 is a component of anchoring filaments localized in the basement membrane region of the skin, cornea, conjunctiva, and other tissues. It interacts with laminin- 6 and -7 to form a stable association with the basement membrane structure (Carter etal., 1991; Kallunki etal., 1992; Ljubimov et al., 1995; Champliaud et al., 1996). LM-5 is induced by thymosin $\beta 4$ in the cornea (Sosne et al., 2004). LM-5 is expressed by migrating keratinocytes and is expressed in hair follicles (Chuang et al., 2003). Furthermore, integrin beta-1, the major receptor component of laminin-5, has a significant role in hair follicle development (Brakebusch et al., 2000; Raghavan et al., 2000) suggesting that thymosin $\beta 4$ may stimulate hair growth, in part, by increasing laminin-5 expression.

The expression of thymosin $\beta 4$ is closely related to the development of certain organs. Thymosin $\beta 4$ has been studied in chick embryogenesis, including the development of the nervous system, cardiovascular system, and feather buds (Dathe et al., 2004). It has been detected in the nervous system of the developing rat brain, and during differentiation of embryonic cells into cardiac cells, thus, suggesting that the expression of thymosin $\beta 4$ may be involved in the development of the nervous system and the heart, (Gomez-Marquez et al., 1993; Gomez-Marquez et al., 1996; Anadon et al., 2001). Thymosin $\beta 4$ is also expressed early in the developing tooth and may be important in dentinogenesis (Akhter et al., 2005). Thus, thymosin $\beta 4$ is likely important in the early development of several organs, but this has not been directly demonstrated. Here, we used over-expressing mice to determine the physiological role of this protein in development.

\section{Results}

\section{Generation of transgenic mice expressing thymosin $\beta 4$ under the control of the keratin $5(K 5)$ promoter and char- acterization of its expression}

First, we expressed the thymosin $\beta 4$ transgene under control of the cytomegalovirus (CMV) promoter. However, we did not get any positive transgenic mice among hundreds of new born pups. We concluded that mice expressing thymosin $\beta 4$ on the CMV promoter died at an early embryonic stage. As thymosin $\beta 4$ is a key protein regulating cell migration, we hypothesize that over-expressing thymosin $\beta 4$ may affect cell migration of early stage embryogenesis resulting in embryonic lethality. Next, we focused on the analysis of thymosin $\beta 4$ functions in ectodermal development. We successfully created an epithelial-specific thymosin $\beta 4$ transgenic mouse model a using keratin 5 promoter. We used this promoter because many functions of thymosin $\beta 4$ occur in the skin, including wound healing and hair growth. The K5-thymosin $\beta 4$ transgene was made by sub-cloning the mouse thymosin $\beta 4$ cDNA into a vector containing a $5.2 \mathrm{~kb}$ fragment of the bovine $\mathrm{K} 5$ promoter, the rabbit $\beta$-globin intron 2 , and the SV40 polyadenylation signal (Fig. 1A). Two founder transgenic mice were identified by PCR analysis of tail DNA using primers specific for the thymosin $\beta 4$ and $\beta$-globin intron (Fig. 1A). All of the transgenic mice grew to normal size and were fertile.

Immunohistochemistry on adult skin sections revealed that both lines of founder mice over-expressed thymosin $\beta 4$ in the skin especially in the hair follicles (Fig. 1B). The over-expression was confirmed by Western blot analysis with total protein from the skins of the transgenic and wild type mice (Fig. 1C).
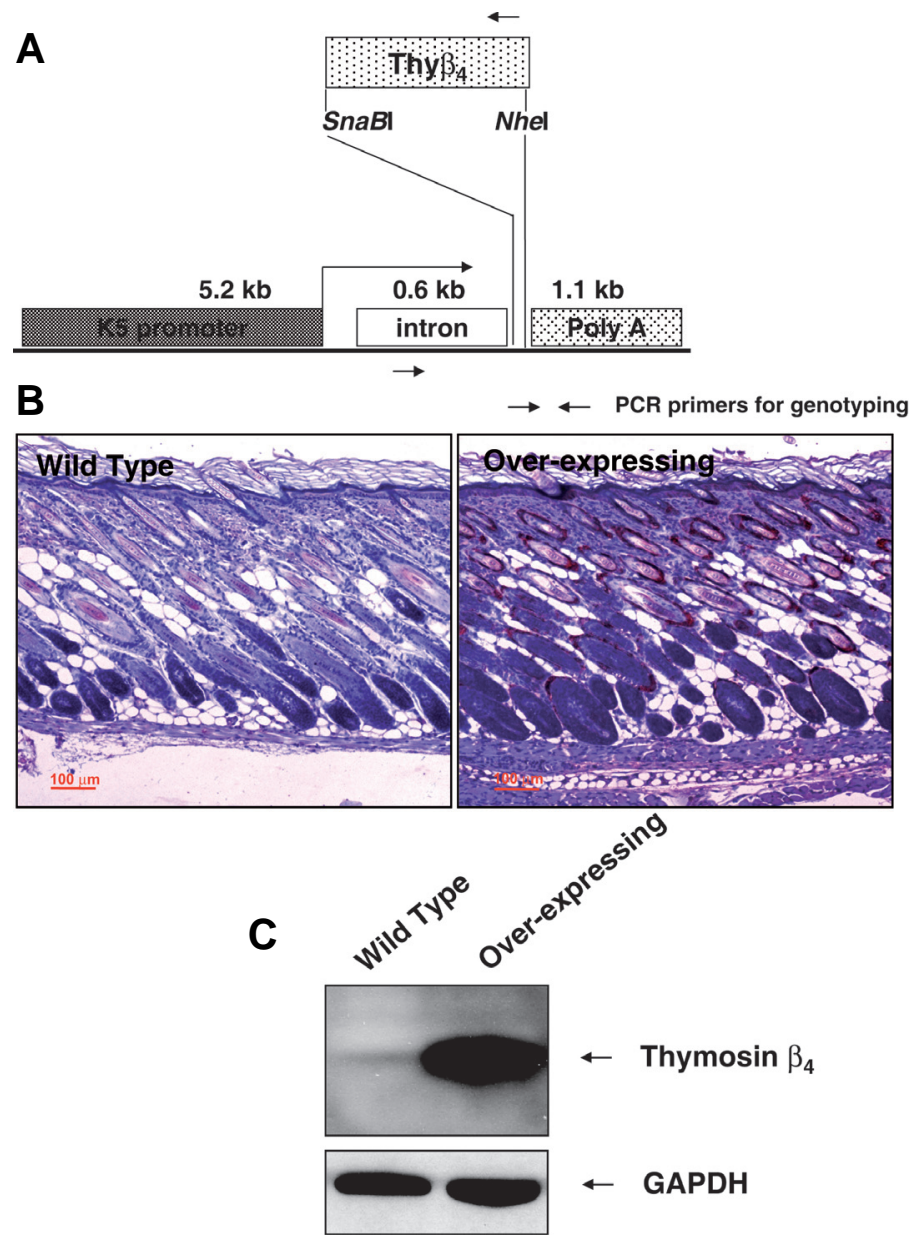

Fig. 1. Generation of thymosin $\boldsymbol{\beta} 4$ over-expressing mice. Construction of the $K 5$ thymosin $\beta 4$ transgene (A). The fragment containing the fulllength mouse thymosin $\beta 4 \mathrm{cDNA}(0.2 \mathrm{~Kb})$ was cut using $\mathrm{SnaBl}$ and Nhe I and inserted into A bluescript KS plasmid containing a $5.2 \mathrm{~kb}$ fragment from the bovine $K 5$ promoter, a $0.6 \mathrm{~kb}$ fragment containing the rabbit $b$ globin intron, and a $1.1 \mathrm{~kb}$ fragment containing two $3^{\prime}$ poly A signal sequences. The transgene was isolated by cutting with Acc65I and injected into the pronuclei of fertilized oocytes of FVB/N mice to create transgenic founder mice. The primer sequences for the detection of the transgene were based on rabbit $\beta$-globin intron and thymosin $\beta 4$ as indicated. Immunohistochemical analysis of thymosin $\beta 4$ expression in the skin of transgenic mice (B). Skins of 6 week old mice were immunostained with a rabbit polyclonal antibody to thymosin $\beta 4$ 11:500 dilution). Antibody binding was detected using a DAKO EnVision-peroxidase system. Western blot analysis thymosin $\beta 4$ expression in the skin of transgenic mice (C). Total lysates from 6 week old mouse skin were separated by electrophoresis and transferred to a polyvinylidene difluoride membrane. The membrane was incubated in rabbit polyclonal thymosin $\beta 4$ (1: 5000 dilution) and GAPDH (1:2000 dilution) and detected with an enhanced chemiluminescence detection kit. 
Expression of thymosin $\beta 4$ during development of transgenic mice embryos was also analyzed by immunohistochemistry from E-7 to P-3 stage. There was no significant difference in thymosin $\beta 4$ expression until E-13 stage mice and over-expressed thymosin $\beta 4$ was detected after E-13 stages (Data not shown). Thymosin $\beta 4$ was highly expressed in the forming anal and nasal cavities (Fig. 2 D,E) and around developing teeth (Fig. 2F). Thymosin $\beta 4$ was also strongly expressed in the outer root sheath of the follicles of the whiskers and in the hair follicles of the transgenic mice (Fig. 2E).

\section{Accelerated hair growth in thymosin $\beta 4$ transgenic mice}

The effect of thymosin $\beta 4$ on hair growth was analyzed in the transgenic mice. We watched the hair growth pattern of transgenic mice after birth but could not detect any differences in the onset of hair growth when compared with the wild type mice. However, we found significant difference in the speed of hair re-growth after shaving. Shaved mice were observed and the

A

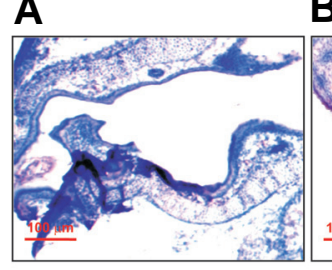

B

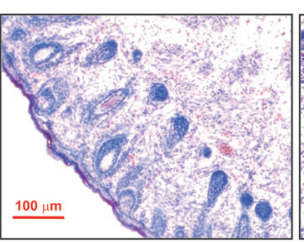

C

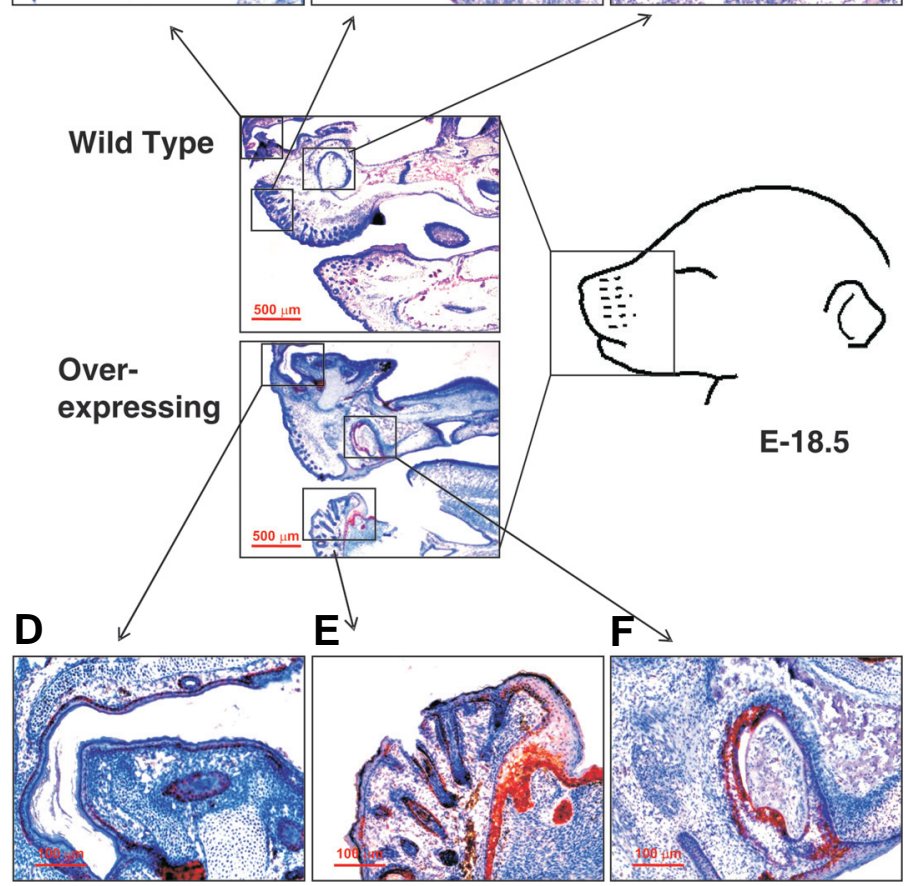

speed of hair re-growth was compared by measuring the hair area on the shaved spot at 2 weeks using an image analysis program. The speed of hair growth on the skin of the transgenic mice was accelerated as shown in Fig. 3. These data suggest that the increased expression of thymosin $\beta 4$ in the hair follicles (Fig. 1B) promoted hair re-growth in the transgenic mice. To analyze the expression pattern of thymosin $\beta 4$ on the hair follicle, we stained for thymosin $\beta 4$ in the skin of transgenic mice. As shown in Fig. 3B, thymosin $\beta 4$ was expressed on

A
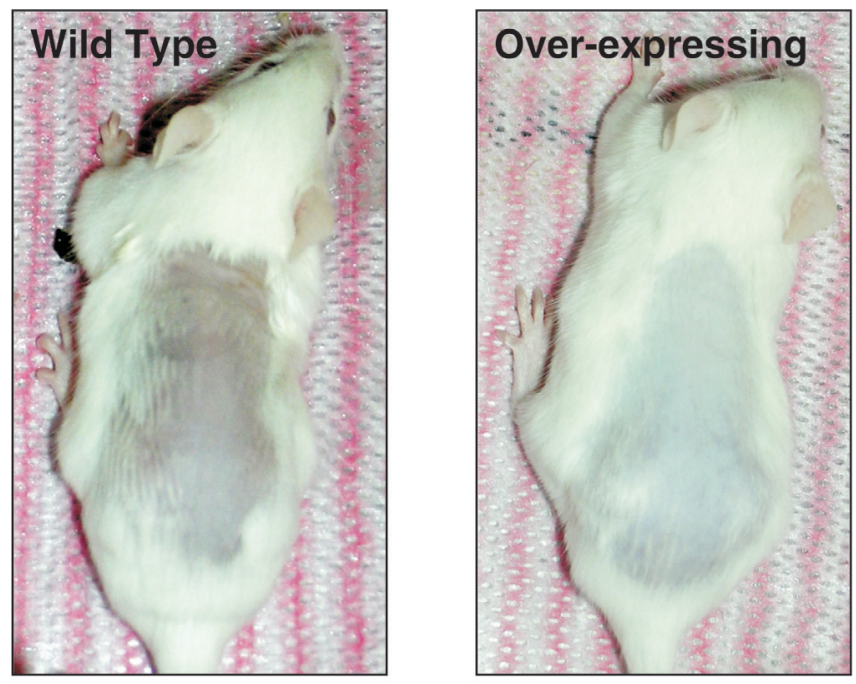

B
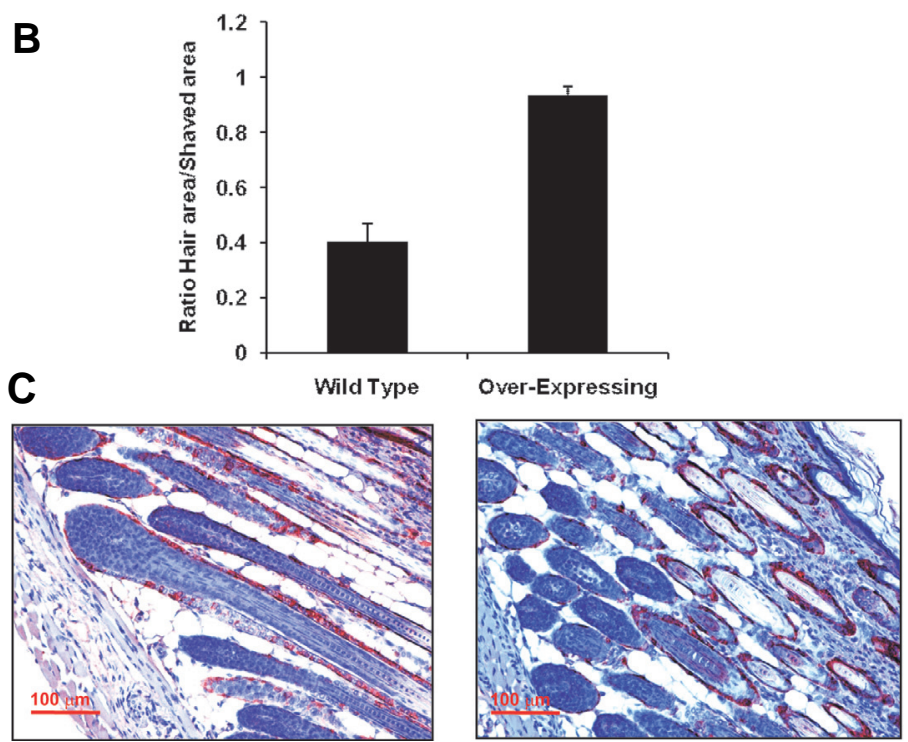

Fig. 2 (Left). Expression of thymosin $\boldsymbol{\beta} 4$ in the developing anal and nasal cavities of transgenic mice. Thymosin $\beta 4$ was highly expressed in the forming anal and nasal cavities (D,E) and around developing teeth (F). Thymosin $\beta 4$ was also strongly expressed in the whiskers and hair of the transgenic mice (E). Immunohistochemical analysis of thymosin $\beta 4$ expression was conducted with 18.5 day mouse embryos. Whole embryos were immunostained with a rabbit polyclonal antibody to thymosin $\beta 4$ (1:500 dilution). The antibody binding was detected with the use of the DAKO EnVisionperoxidase system.

Fig. 3 (Right). Analysis of hair re-growth. The effect of thymosin $\beta 4$ on hair growth was analyzed in cycling wild type and transgenic mice. Shaved mice were observed for 2 weeks at which time the photos were taken (A). To compare the speed of hair growth, white colored hair area was measured and divided by whole shaved area using image analysis software, Image J. Six mice were used for each group and the experiment was repeated three times (B). Expression of thymosin $\beta 4$ in the hair of transgenic mice. Thymosin $\beta 4$ was highly expressed on the surface of the hair follicles especially on the external root sheath (C). 
A
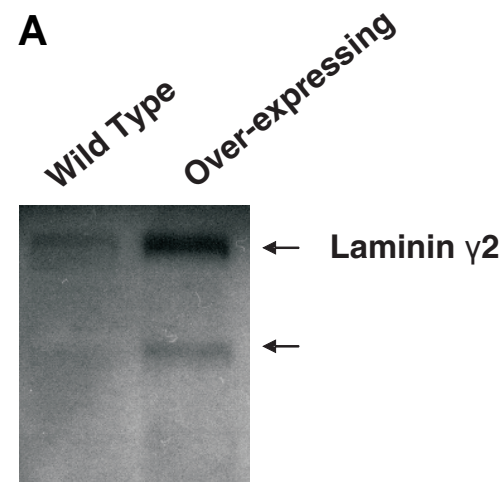

B
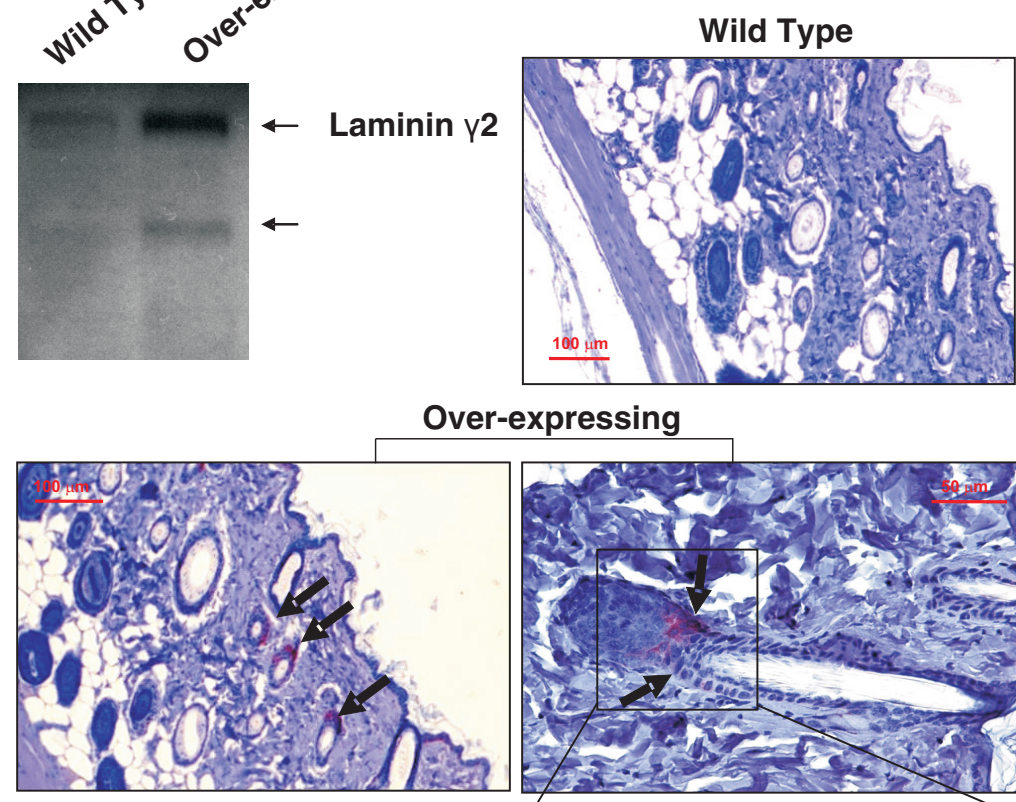

Fig. 4. Expression and localization of laminin- 5 in thymosin $\boldsymbol{\beta} 4$ overexpressing mice. Western blot analysis of laminin-5 in the skin of transgenic mice (A). Total lysates from 6 week old mice skin were separated by electrophoresis and transferred to a polyvinylidene difluoride membrane. The membrane was incubated with rabbit polyclonal laminin $\gamma 2$ (1: 1000 dilution) and detected with an enhanced chemiluminescence detection kit. Immunohistochemical analysis of laminin-5 in the skin of transgenic mice (B). Skins of 6 week old mice were immunostained with a rabbit polyclonal antibody to laminin $\gamma 2$ (1: 100 dilution). The antibody binding was detected using a DAKO EnVision peroxidase system.

surface of the hair follicles especially in the external root sheath.

\section{Induced expression of laminin-5 in thymosin $\beta 4$ transgenic mice}

We examined the expression of laminin- 5 in the thymosin $\beta 4$ over-expressing mice since laminin- 5 was one of the candidate genes associated with hair growth among the proteins upregulated by thymosin $\beta 4$. Western blot analysis and immunohistochemistry were used with the skin of wild type and transgenic mice to characterize the expression of laminin-5. As shown in Fig. 4A, Western blot shows that the expression of laminin- 5 was increased approximately 5 -fold in the transgenic mice relative to the wild type mice. Immunohistochemistry showed that the expression of laminin- 5 was specifically increased in the root of the hair follicles and this staining pattern is different from that of thymosin $\beta 4$ (Fig. 4B). The expression of laminin- 5 around the root of the hair follicle suggests that laminin- 5 is induced by the over-expression of thymosin $\beta 4$ and that this induced laminin-5 expression may stimulate hair follicle stem cells and play a role in the thymosin $\beta 4$ stimulated hair growth.

\section{Unusual tooth morphology in thymosin $\beta 4$ transgenic mice}

Thymosin $\beta 4$ was highly expressed around developing teeth in the transgenic mice. In addition, thymosin $\beta 4$ was reported to be elevated in tooth development at embryonic day $13(\mathrm{E}-13)$ of tooth development and decreased after birth (Akhter et al., 2005). These data suggest that thymosin $\beta 4$ plays an important role in tooth development. Tooth morphology was further analyzed in the transgenic mice. As shown in Fig. 5, the morphology of teeth of the transgenic mice was significantly different from that of the wild type mice. The teeth are fragile and show a chalky color, indicating enamel hypoplasia similar to the teeth from the ameloblastin or amelogenin knockout mouse (Fukumoto et al., 2004) (Fig. 5A). As shown in x-ray photography, the teeth have dull incisors compared to the teeth of wild type mice (Fig. 5B). We have examined more than 20 mice and $100 \%$ of the transgenic mice have this phenotype. These data suggest that over-expression of thymosin $\beta 4$ causes abnormal tooth development, and indicates that thymosin $\beta 4$ plays an important role in enamel matrix deposition and/or production.

\section{Discussion}

Thymosin $\beta 4$ is the most abundant $\beta$-thymosin in mammals. It forms a 1:1 complex with ATP-G-actin (monomeric actin) and inhibits the polymerization of actin (Safer et al., 1991). Thymosin $\beta 4$ plays an important role in cell motility due to its participation in the rapid polymerization/depolymerization of actin (Pantaloni and Carlier, 1993; Kang et al., 1999). Recently, diverse functional roles of thymosin $\beta 4$ have also been reported, including angiogenesis (Grant et al., 1995; Grant et al., 1999), wound healing (Philp et al., 2004), and tumorigenesis (Wang et al., 2004). To investigate the role of thymosin $\beta 4$ in vivo, we constructed transgenic mice over-expressing thymosin $\beta 4$. Highly expressed thymosin $\beta 4$ in the skin accelerated hair growth and induced abnormally-shaped white teeth and dull incisors. These results suggest that the keratin 5 promoter stimulated high expression of thymosin $\beta 4$ in hair follicles and in germ line stem cells regulating tooth development.

A recent study showed that thymosin $\beta 4$ promotes laminin- 5 (LM-5) expression (Sosne et al., 2004). Using gene expression analysis with human corneal epithelial cells treated with thymosin $\beta 4$, the laminin- $5 \gamma 2$ chain was increased by more than 2 -fold over untreated cells. LM- 5 is one of the proteins involved in hair growth. The expression of LM-5 is highly increased in hair follicles (Chuang et al., 2003). In addition, hair follicle integrity is dependent on keratinocyte expression of integrin $\beta 1$, the major receptor component of laminin-5 (Brakebusch et al., 2000). Furthermore, conditional ablation of integrin $\beta 1$ results in severe defects in hair follicle invagination (Raghavan et al., 2000). These studies as well as ours suggest that thymosin $\beta 4$ increased LM- 5 expression and that this induction of LM- 5 stimulated hair growth. As shown in Fig. 5, LM-5 expression in the skin was increased in thymosin 


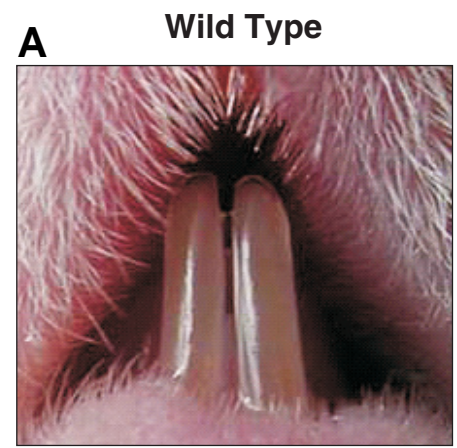

\section{B Over-expressing}
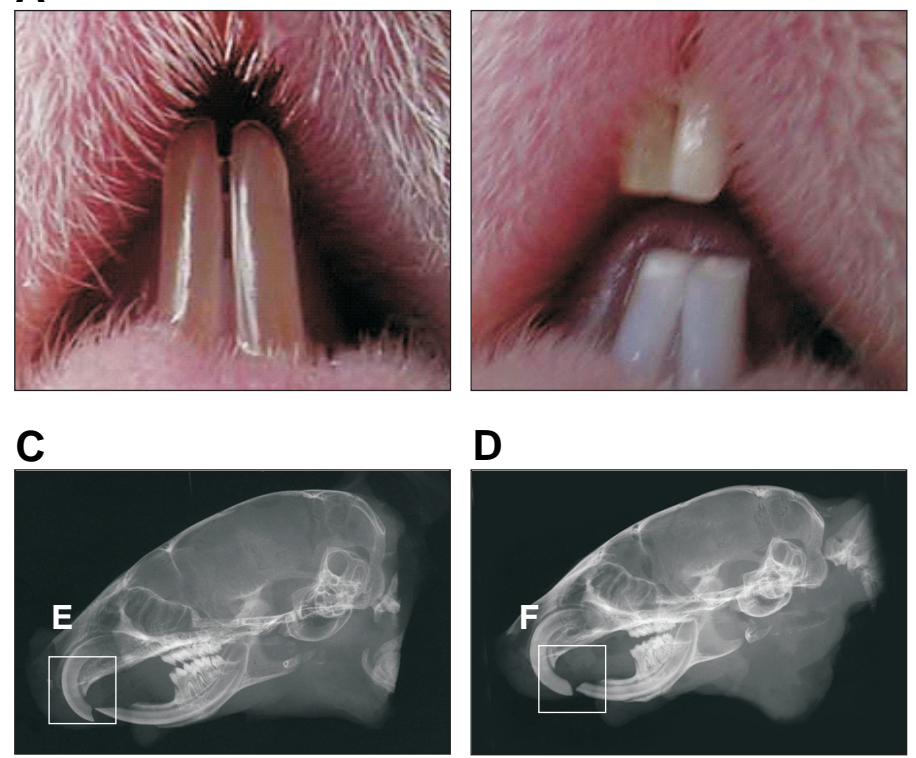

E

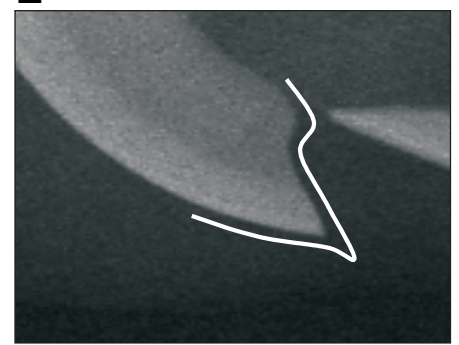

$\mathbf{F}$

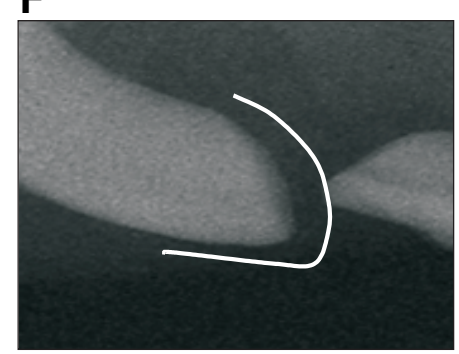

Fig. 5. Tooth morphology of thymosin $\beta 4$ over-expressing mice. The teeth of the transgenic mice were blunter due to significant fragility and they appeared chalky in color, indicating enamel hypoplasia (A,B). X-ray photography shows that the teeth from the transgenic mice have dull incisors compared to the teeth of wild type mice (C,D,E,F).

$\beta 4$ over-expressing mice and this induction of LM- 5 was concentrated in hair follicles.

The involvement of thymosin $\beta 4$ in tooth development was previously reported by Akhter et al. (Akhter et al., 2005) who identified thymosin $\beta 4$ expression in early tooth development. We found (Fig. 5) that over-expression of thymosin $\beta 4$ affected tooth development resulting in fragile teeth that have a chalky color, indicating enamel hypoplasia similar to the ameloblastin knockout mouse teeth (Fukumoto et al., 2004). These phenotype is also similar to the urokinase-type plasminogen (u-PA) activator overexpressing mice controlled by kertain 5 promoter (Zhou et al., 1999). These results suggested that keratin 5 promoter was expressed at the site of teeth development and that thymosin $\beta 4$ also plays an important role in tooth development like u-PA. In ectodermal organs, including hair follicles, skin, and ectodermal derivatives of teeth, the morphology of the initial developmental stage is similar and shares many genes, which are involved in cell proliferation and in differentiation (Nakamura et al., 2004). We suggest that over-expressing thymosin $\beta 4$ may affect teeth germ cell migration since thymosin $\beta 4$ has been found to promote the migration of many cell types (Akhter et al., 2005). It is also possible that high amounts of thymosin $\beta 4$ disturb dental epithelial cell polarization by inhibiting actin polymerization in preameloblast and/or integrin expression, because dental epithelial polarization is important for secretion of enamel matrix and migration of ameloblasts.

\section{Materials and Methods}

\section{Construction of the $K 5$ thymosin $\beta 4$ transgene and generation of transgenic mice}

A bluescript KS plasmid containing a $5.2 \mathrm{~kb}$ fragment from the bovine $\mathrm{K} 5$ promoter, a $0.6 \mathrm{~kb}$ fragment containing the rabbit $\beta$-globin intron, and a $1.1 \mathrm{~kb}$ fragment containing two 3' poly A signal sequences (Angela et al., 1998) were obtained from Dr. Yoshi Yamada (NIH, MD, USA). This plasmid was derived from constructs originally obtained from Dr. Jose Jorcano (CIEMAT, Madrid, Spain). A $0.2 \mathrm{~kb}$ fragment containing the full-length mouse thymosin $\beta 4$ cDNA was cut using $\mathrm{SnaBI}$ and Nhe I and inserted into the $\mathrm{K} 5$ vector. The transgene was isolated by cutting with Acc65I followed by sucrose gradient centrifugation. The purified fragment was injected into the pronuclei of fertilized oocytes of FVB/N mice to create transgenic founder mice (Sreenath et al., 1999). The founder mice were back-crossed to the wild type $\mathrm{FVB} / \mathrm{N}$ mice and analyzed. Integration of the transgene in the founder mice was detected by either Southern blot or PCR analysis. DNA was isolated from tail biopsies using classical proteinase $\mathrm{K}$ digestion. For Southern blot analysis, 10 ug of genomic DNA was digested overnight by $K p n l$ and hybridized with a $0.2 \mathrm{~kb}$ fragment containing thymosin $\beta 4$. For PCR analysis, 0.5 ug of genomic DNA was amplified for 35 cycles using Takara ExTaq DNA polymerase. The primer sequence for detection of the transgene was designed based on the rabbit $\beta$-globin intron and thymosin $\beta 4$ as indicated at Fig. 1. For all experiments, a minimum of 5 animals were used for each data point and each experiment was repeated at least three times.

\section{Western blot analysis and immunostaining}

Western blot analysis was conducted as described (Champliaud et al., 1996). Briefly, $100 \mu \mathrm{g}$ of lysate from 6 - week old mice skin was separated by electrophoresis on a Novex 4-20\% Tris-glycine gel (Invitrogen, CA, USA). The protein concentrations of the lysates were determined by the bicinchoninic acid protein assay system (Pierce, Rockford, IL), and equal protein amounts of each sample were separated by electrophoresis on Novex 4-20\% Tris-glycine gels. Equal protein loading was confirmed by Coomassie blue staining of duplicate gels after electrophoresis. The gels were incubated for 1 hour in phosphate-buffered saline (PBS) containing 10\% glutaraldehyde (Sigma-Aldrich, St. Louis, MO), washed three times for 20 minutes in PBS, and further incubated in a blotting buffer containing Novex Trisglycine transfer buffer (Invitrogen) and 20\% methanol for 30 minutes at room temperature. Proteins were transferred to a polyvinylidene difluoride membrane (Invitrogen) by electrotransfer. The membrane was pre-incubated for 2 hours in Tris Buffered Saline (TBS) containing $5 \%$ skim milk and $0.05 \%$ Tween 20 (TBS-T). The membrane was incubated for 1 hour at room temperature in TBS-T plus antibodies (rabbit polyclonal thymosin $\beta 4,1: 5000$ dilution; ALPCO Diagnostics, Windham, NH) or with rabbit polyclonal laminin $\gamma 2$ (1: 1000 dilution). The membranes were washed five times with PBS-T and then incubated with a species-appropriate horseradish peroxidase-conjugated secondary antibody (Santa Cruz Biotechnology) for 1 hour at room temperature. The membranes were washed four times with TBS-T, and bound antibody was detected with an enhanced chemiluminescence detection kit (Amersham Biosciences, Buckinghamshire, UK). For immunohistochemistry, the skin of 6 week old mice or whole embryos at various stages were fixed with $4 \%$ formaldehyde (SigmaAldrich) and paraffinized. The sections were deparaffinized and immunostained with a rabbit polyclonal antibody to thymosin $\beta 4$ (1: 
500 dilution) or laminin $\gamma 2$ (1: 100 dilution). The antibody binding was detected with the use of an EnVision peroxidase system (DAKO, Carpinteria, CA).

\section{Analysis of hair growth}

The effect of thymosin $\beta 4$ on hair growth was analyzed in 28 day old (cycling) wild type and transgenic mice. Shaved mice were observed for 2 weeks at which time photos were taken. To compare the speed of hair growth, white colored hair area was measured and divided by whole shaved area using image analysis software (Image J, NIH, Bethesda, MD). Six mice were used for each group and the experiment was repeated three times.

\section{Radiographic analysis}

After euthanization with $\mathrm{CO}_{2}, 6$-week-old mouse heads were dissected out and sliced sagittally into two symmetrical halves. Tooth mineral density was analyzed by a microradiographic technique using $X$ ray imaging with a standard setting of $110 \mathrm{sec} \times 20 \mathrm{kV}$ (Model MX20, Faxitron x-ray Corporation, Wheeling, IL). Six mice were used for each group and the experiment was repeated three times.

\section{Acknowledgements}

This work was supported by the National Research Foundation of Korea (NRF) grant funded by the Korea government (MEST) (KRF20090066740) and a grant from the Kosin University College of Medicine (2007).

\section{References}

AKHTER, M., KOBAYASHI, I., KIYOSHIMA, T., MATSUO, K., YAMAZA, H., WADA, H., HONDA, J.Y., MING, X., and SAKAI, H. (2005). Possible functional involvement of thymosin beta 4 in developing tooth germ of mouse lower first molar. Histochem. Cell. Biol. 124: 207-213.

ANADON, R., RODRIGUEZ, MOLDES I., CARPINTERO, P., EVANGELATOS, G., LIVIANOU, E., LEONDIADIS, L., QUINTELA, I., CERVINO, M.C., and GOMEZMARQUEZ, J. (2001). Differential expression of thymosins beta(4) and beta(10) during rat cerebellum postnatal development. Brain Res. 894: 255-265.

ANGELA, M.P., SUSAN, M.F., CLAUDIO, J.C., and DAVID, G.J. (1998). Deregulated expression of E2F1 induces hyperplasia and cooperates with ras in skin tumor development. Oncogene 16: 1267-1276.

BRAKEBUSCH, C., GROSE, R., QUONDAMATTEO, F., RAMIREZ, A., JORCANO, J.L., PIRRO, A., SVENSSON, M., HERKEN, R., SASAKI, T., TIMPL, R., WERNER, S., and FASSLER, R. (2000). Skin and hair follicle integrity is crucially dependent on beta 1 integrin expression on keratinocytes. EMBOJ.19: 3990-4003.

BURGESON, R.E., CHIQUET, M., DEUTZMANN, R., EKBLOM, P., ENGEL, J., KLEINMAN, H., MARTIN, G.R., MENEGUZZI, G., PAULSSON, M., SANES, J., et al.,1994). A new nomenclature for the laminins. Matrix Biol. 14: 209-211.

CARTER, W.G., RYAN, M.C., and GAHR, P.J. (1991). Epiligrin, a new cell adhesion ligand for integrin alpha 3 beta 1 in epithelial basement membranes. Cell 65: 599-610.

CHA, H.J., JEONG, M.J., and KLEINMAN, H.K. (2003). Role of Thymosin beta-4 in tumor metastasis and angiogenesis. J. Natl. Cancer Inst. 95: 1674-1680.

CHAMPLIAUD, M.F., LUNSTRUM, G.P., ROUSSELLE, P., NISHIYAMA, T., KEENE, D.R., and BURGESON, R.E. (1996). Human amnion contains a novel laminin variant, laminin 7 , which like laminin 6 , covalently associates with laminin 5 to promote stable epithelial- stromal attachment. J. Cell Biol. 132: 1189-1198.

CHUANG, Y.H., DEAN, D., ALLEN, J., DAWBER, R. and WOJNAROWSKA, D.F. (2003). Comparison between the expression of basement membrane zone antigens of human interfollicular epidermis and anagen hair follicle using indirect immunofluorescence. Br. J. Dermatol. 149: 274-278.

DATHE, V., and BRAND-SABERI, B.(2004). Expression of thymosin beta-4 during chick development. Anat Embryol (Berl) 208: 27-32.

FUKUMOTO, S., KIBA, T., HALL, B., IEHARA, N., NAKAMURA, T., LONGENECKER,
G., KREBSBACH, P.H., NANCI, A., KULKARNI, A.B., and YAMADA,Y. (2004). Ameloblastin is a cell adhesion molecule required for maintaining the differentiation state of ameloblasts. J. Cell. Biol. 167: 973-983.

GOMEZ-MARQUEZ, J., FRANCO DEL AMO, F., CARPINTERO, P., and ANADON R. (1996). High levels of mouse thymosin beta-4 mRNA in differentiating P19 embryonic cells and during development of cardiovascular tissues. Biochim. Biophys. Acta. 1306: 187-193.

GOMEZ-MARQUEZ, J., PEDRARES, J.I., OTERO, A., and ANADON, R. (1993). Prominent expression of the actin-sequestering peptide Fx gene in the hippocampal region of rat brain. Neurosci. Lett. 152: 41-44.

GRANT, D.S., KINSELLA, J.L., KIBBEY, M.C., LAFLAMME, S., BURBELO, P.D., GOLDSTEIN, A.L., and KLEINMAN, H.K. (1995). Matrigel induces thymosin beta 4 gene in differentiating endothelial cells. J. Cell Sci. 108: 3685-3694.

GRANT, D.S., ROSE, W., YAEN, C., GOLDSTEIN, A., MARTINEZ, J., AND KLEINMAN, H.K. (1999). Thymosin beta-4 enhances endothelial cell differentiation and angiogenesis. Angiogenesis 3: 125-135.

KALLUNKI, P., SAINIO, K., EDDY, R., BYERS, M., KALLUNKI, T., SARIOLA, H., BECK, K., HIRVONEN H., SHOWS, T.B., and TRYGGVASON, K. (1992). A truncated laminin chain homologous to the B2 chain: structure, spatial expression, and chromosomal assignment. J. Cell Biol. 119: 679-693.

KANG, F., PURICH, D.L., and SOUTHWICK, F.S. (1999). Profilin promotes barbedend actin filament assembly without lowering the critical concentration. J. BiOl Chem 274: 36963-36972.

LJUBIMOV V., BURGESON R.E., BUTKOWSKI R.J., MICHAEL A.F., SUN T.T., and KENNEY M.C. (1995). Human corneal basement membrane heterogeneity: topographical differences in the expression of type IV collagen and laminin isoforms. Lab. Invest. 72: 461-473.

NAKAMURA T., UNDA F., DE-VEGA S., VILAXA A., FUKUMOTO S., YAMADA K.M., and YAMADA Y. (2004). The Krüppel-like factor epiprofin is expressed by epithelium of developing teeth, hair follicles, and limb buds and promotes cell proliferation. J. Biol. Chem. 279: 626-634

PANTALONI, D., and CARLIER, M.F. (1993). How profiling promotes actin filament assembly in the presence of thymosin $\beta 4$. Cell 75: 1007-1014.

PHILP, D., GOLDSTEIN, A.L., and KLEINMAN, H.K. (2004). Thymosin $\beta 4$ promotes angiogenesis, wound healing, and hair follicle development. Mech. Ageing Dev. 125: 113-115.

PHILP, D., NGUYEN, M., SCHEREMETA, B., ST.-SURIN, S., VILLA, A.M., ORGEL, A., KLEINMAN, H.K., and ELKIN, M. (2004). Thymosin beta-4 increases hair growth by activation of hair follicle stem cell. FASEB J. 18: 385-387.

RAGHAVAN, S., BAUER, C., MUNDSCHAU, G., Li, Q., and FUCHS, E. (2000). Conditional ablation of beta1 integrin in skin. Severe defects in epidermal proliferation, basement membrane formation, and hair follicle invagination. $J$. Cell Biol. 150: 1149-1160.

SAFER, D., ELZINGA, M., and NACHMIAS, V.T. (1991). Thymosin beta 4 and FX, an actin-sequestering peptide, are indistinguishable. J. Biol Chem 266: 40294032.

SOSNE, G., XU, L., PRACH, L., MROCK, L.K., KLEINMAN, H.K., LETTERIO, J.J., HAZLETT, L.D., and KURPAKUS-WHEATER, M. (2004). Thymosin beta 4 stimulates laminin-5 production independent of TGF-beta. Experimental Cell Research 293: 175-183.

SREENATH, T.L., CHO, A., MACDOUGALL, M., and KULKARNI, A.B. (1999). Spatial and temporal activity of the dentin sialophosphoprotein gene promoter: differential regulation in odontoblasts and ameloblasts. Int. J. Dev. Biol. 43 : 509-516.

VERMA, A. K. and BOUTWELL, R.K., (1980). Effects of dose and duration of treatment with the tumor-promoting agent, 12-O-tetradecanoylphorbol-13-acetate on mouse skin carcinogenesis. Carcinogenesis 1:271-276.

WANG, W.S., CHEN, P.M., HSIAO, H.L., WANG, H.S., LIANG, W.Y., and SU, Y (2004). Overexpression of the thymosin $\beta$ - 4 gene is associated with increased invasion of SW480 colon carcinoma cells and the distant metastasis of human colorectal carcinoma. Oncogene 23: 6666-6671.

ZHOU H.M., NICHOLS, A., WOHLWEND, A., BOLON, I., and VASSALLI, J.D. (1999). Extracellular proteolysis alters tooth development in transgenic mice expressing urokinase-type plasminogen activator in the enamel organ. Development 126: 903-912. 


\section{Further Related Reading, published previously in the Int. J. Dev. Biol.}

See our Special Issue Epigenetics and Development edited by Saadi Khochbin and Stefan Nonchev at: http://www.ijdb.ehu.es/web/contents.php?vol=53\&issue=2-3

See our Special Issue Skin Development edited by Danielle Dhouailly at:

http://www.ijdb.ehu.es/web/contents.php?vol=48\&issue=2-3

Hair cell regeneration in the avian auditory epithelium

Jennifer S. Stone and Douglas A. Cotanche

Int. J. Dev. Biol. (2007) 51: 633-647

BMP signalling in craniofacial development

Xuguang Nie, keijo Luukko and Paivi Kettunen

Int. J. Dev. Biol. (2006) 50: 511-521

Detection of differentially expressed genes in the early developmental stage of the mouse mandible.

H Yamaza, K Matsuo, T Kiyoshima, N Shigemura, I Kobayashi, H Wada, A Akamime and H Sakai

Int. J. Dev. Biol. (2001) 45: 675-68

Differential expression of laminin-5 subunits during incisor and molar development in the mouse.

K Yoshiba, N Yoshiba, D Aberdam, G Meneguzzi, F Perrin-Schmitt, C Stoetzel, J V Ruch and H Lesot

Int. J. Dev. Biol. (2000) 44: 337-340

Timing of the expression of enamel gene products during mouse tooth development.

M Zeichner-David, H Vo, H Tan, T Diekwisch, B Berman, F Thiemann, M D Alcocer, P Hsu, T Wang, J Eyna, J Caton, H C Slavkin and M MacDougall

Int. J. Dev. Biol. (1997) 41: 27-38

Integrin regulatory switching in development: oscillation of beta 5 integrin mRNA expression during epithelial-mesenchymal interactions in tooth development.

$S$ Yamada, K M Yamada and K E Brown

Int. J. Dev. Biol. (1994) 38: 553-556

5 yr ISI Impact Factor $(2008)=3.271$
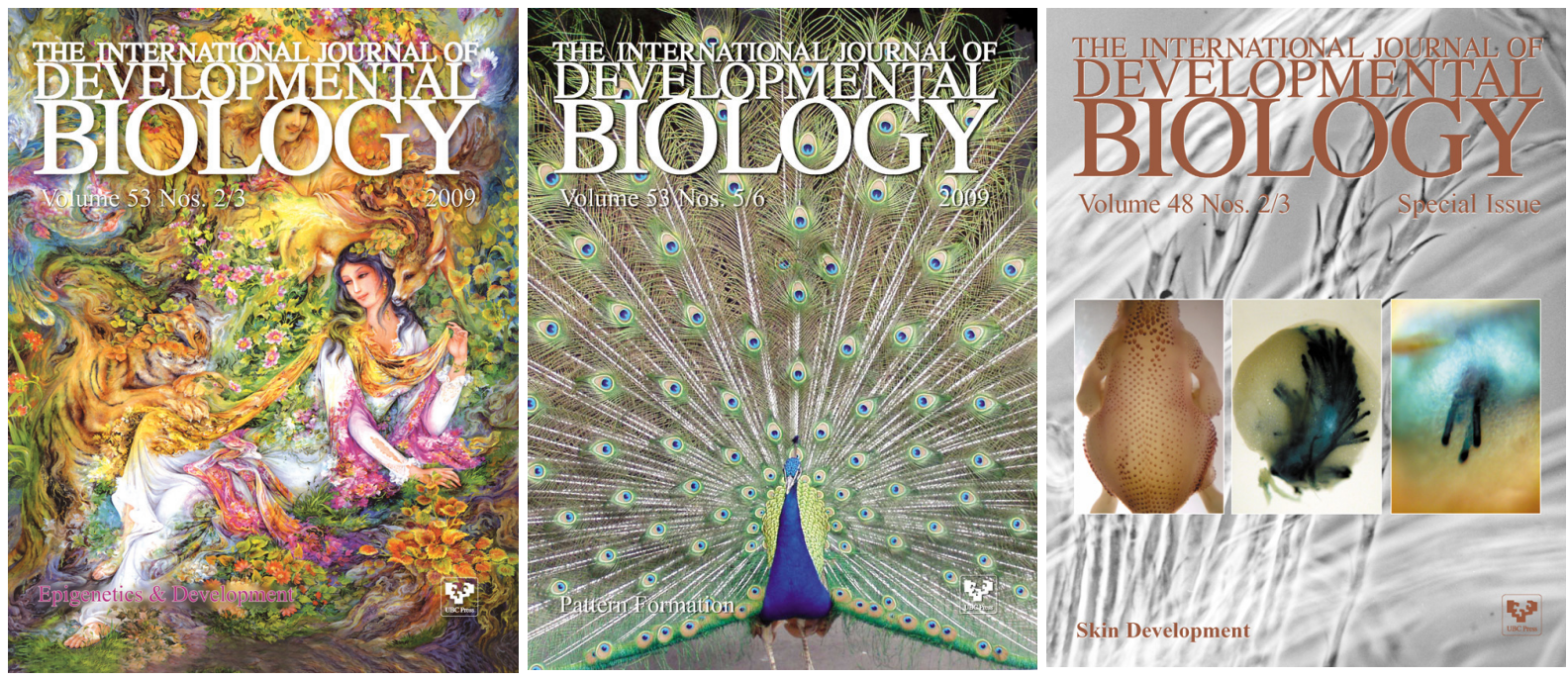